chair of the University of Illinois's department of political science. In 1989, she moved from Illinois to the University of South Carolina.

Betty was a dedicated teacher and an exemplary mentor to untold numbers of graduate students whose careers were enhanced with her care and guidance. As a pioneer and role model for women throughout the political science profession, she also was one of the first women to challenge prevailing conventions and gender discrimination in the discipline, and one of the first to attain national and international stature. As a result, she won many awards for both scholarship and leadership throughout her long career, including the Frank D. Goodnow Award from the APSA for a lifetime of contributions and service to the discipline and the Harold Lasswell Award from the International Society for Political Psychology for a lifetime of outstanding contributions to political psychology. In 2007, she received a distinguished alumna award from the University of Utah. She served in many posts and positions, including as president of the International Society for Political Psychology, president of the Presidency Research Section of the APSA, and vice-president of the APSA.

Betty's interests and scholarly contributions were wide-ranging, but she was particularly interested in the social psychology of political leadership. Her books and articles include analyses of the leadership styles of six recent American presidents, as well as Mikhail Gorbachev, Boris Yeltsin, Wilhelm deKlerk, Nelson Mandela, and many others. She was always fascinated by and attracted to and yet wary of both politics and political leadership. This was due mainly to her deep knowledge of many political leaders and the triumphs and tragedies of political history in which they played a part, but it was due also to her own experiences as an academic leader, political activist, and reflective citizen. Betty was a committed democrat, and also a committed Democrat, but her love of justice far transcended her other political commitments and fascinations. She enjoyed music and ballroom dancing, and, of course, reading and good conversation.

Intellectually vigorous to the end, Betty's successful career as a scholar and teacher, mentor and leader, was aided in no small measure by her personal courage, strength, and tenacity. These virtues also served her well in the last few years of her life, when she continued her work while combating a great many physical challenges. Betty is now buried next to her parents in Salt Lake City, Utah. She is survived by her brother and sister-in-law, Jay and Edris Glad, and by her great-nephew and -niece, Christine and Jason Stout, and many close cousins. She also leaves behind many friends, colleagues, and former students in the United States and many other nations. A memorial service was held in the Rutledge College Chapel on the historic Horseshoe of the University of South Carolina, Columbia, on Sunday, August 8, 2010.

Daniel Sabia, Jr. University of South Carolina Laura R. Woliver University of South Carolina

\section{ARNOLD KANTER}

It is with deep sadness that we report the passing of our friend and colleague Arnold Kanter on April 10, 2010, at the all-tooyoung age of 65 . He died from acute myelogenous leukemia, diagnosed in 2007.

Arnie trained as an academic political scientist, earning his undergraduate degree at the University of Michigan (1965) and his M.Phil. (1968) and Ph.D. (1975) at Yale. But his exemplary career as a teacher, public servant, policy analyst, and statesman provides an impressive demonstration of the diverse endeavors to which that training can profitably be applied.

His career began in academic fashion, with two years as a Brookings Fellow (1969-71), a year as a lecturer in the department of political science at Ohio State, and a stint as an assistant professor with joint appointments at the Institute of Public Policy Studies and the department of political science at the University of Michigan until 1977. During this early period, he published his dissertation as Defense Politics: A Budgetary Perspective; co-edited with Morton H. Halperin the 1973 volume Readings in American Foreign Policy: A Bureaucratic Perspective; and assisted on Halperin's seminal Bureaucratic Politics \& Foreign Policy (1974), a book that remains a classic today, having been revised in a second edition in 2006. He continued to write and publish journal articles and op-ed essays throughout his life.

It was in 1977 that academic political science suffered a loss, while government and the public interest scored a major gain.
Arnie accepted a position in the Department of State's Bureau of Political-Military Affairs, serving as a Council on Foreign Relations Fellow as a mid-level analyst, followed very quickly by promotion to Deputy Office Director in that bureau. He soon realized that the structure and sometimes frustrating operating requirements of the bureaucracy can also present great opportunities to those who learn to navigate them and to turn the characteristics and peculiarities of government to their advantage. His academic training in bureaucratic politics no doubt helped him to do just that. One of us observed him close at hand during this period and saw him become one of the best bureaucratic operatives ever, without sacrificing his strengths as a policy analyst. It is very difficult to carry out both functions equally well, but he easily managed to do so. Arnie's talents were soon recognized, and within eight years, he was asked to take on important assignments as Principal Deputy Assistant Secretary of State for Political-Military Affairs, and as a senior aide to the Under Secretary of State for Political Affairs, Lawrence Eagleburger.

In 1985 , he left government for the RAND Corporation, where he served first as associate director of the International Security and Defense Program, and then as director of the National Security Strategies Program. In 1989, he returned to government as Senior Director for Defense Policy and Arms Control on Brent Scowcroft's National Security Council staff, an assignment that carried with it the title of Special Assistant to the President for National Security Affairs. In 1991, Secretary of State James Baker brought him back to the Department as Under Secretary for Political Affairs, the department's thirdranking position. In that capacity, he was largely responsible for the day-to-day management of U.S. foreign policy. In 1992 and early 1993, after Secretary Baker departed the State Department for the White House and Larry Eagleburger, as the Deputy Secretary, acted as Secretary and ultimately was named Secretary on a recess appointment, Kanter was sometimes called upon to carry out the Deputy Secretary's responsibilities, and even those of the Secretary when Eagleburger was absent. During his two tours at State and with the NSC, he was a primary participant in developing and negotiating the SALT I and SALT II treaties, and in other arms control negotiations involving the USSR and North Korea. 
The ultimate stage of his varied career began in 1993, when he became a founding member of the Scowcroft Group, an international investment advisory firm, at which he specialized in guiding firms seeking business opportunities in China and Russia. He continued in this capacity for the rest of his life.

Leaving government did not mean the end of Arnie's deep commitment to public service. He belonged to the Council on Foreign Relations, the Trilateral Commission, the International Institute of Strategic Studies, and the Aspen Strategy Group, and he was a member and director of the Atlantic Council of the United States. He served as a member of the President's Foreign Intelligence Advisory Board from 2001-05, and on several presidential advisory groups, panels, and commissions. He also advised the director of the CIA, the National Security Agency, and the Department of Defense.

The positions he held and the work he did does not capture the essence of Arnie Kanter. Fred Kempe, President and CEO of the Atlantic Council, characterized him as a "brilliant, kind, provocative, incisive, humorous, demanding, helpful, irreverent thinker and actor." His Scowcroft Group colleagues Brent Scowcroft, Ginny Mulberger, and Eric Melby called him "a totally engaged, brilliant strategic thinker, one of the quiet but true national treasures and... the kindest and most loyal of friends." And CIA Director Leon Panetta said he was "one of America's brightest minds on intelligence and foreign policy." We concur. But for the signers of this memorial, who knew him first as "Young Arnold" when we all started graduate school together in 1966 and 1967, what was most impressive was that, except for a few pounds here and there, he always remained exactly the same funny, helpful, irascible, down-to-earth friend we knew as young graduate students. We never heard from him about the high positions he attained or the important men in government who became his champions and relied heavily on his counsel. More than one of us benefited directly from his help and advice, yet he never begrudged us the time this required from his busy schedule. Nor could one easily know of personal tragedies he and his wife endured, most notably the loss of a son in infancy. Whatever adversity Arnie encountered, he carried on positively and with great good will.

Arnold Kanter is survived by his wife of 40 years, Anne Strassman Kanter of
McLean, Virginia, and two children, Clare Kanter of New York City and Noah Kanter of Washington, D.C., as well as his brother Robert.

Lawrence Eagleburger and Brent Scowcroft met Arnie long after we did. Not part of our graduate school group, they did not join us in writing this statement. But they wish to be associated with the sentiments we express.

\section{William I. Bacchus U.S. Department of State/ U.S. Agency for International Development, retired Stanley I. Bach Congressional Research Service, Library of Congress, retired Gary C. Jacobson University of California, San Diego David Seidman U. S. Department of Justice Harvey Starr University of South Carolina}

\section{VICTOR T. LE VINE}

Victor T. Le Vine, professor emeritus of political science, analyst, and commentator, died on May 7, 2010, after a brief illness. Le Vine, an only son, was born in Berlin in 1928. His family fled Nazi Germany and lived in France until they immigrated to the United States in 1938. A polyglot, fluent in French, German, and Russian, he was a rigorous researcher, a dedicated teacher, and an encyclopedic repository of classical works in politics, history, literature, and music. He mentored hundreds of graduate and undergraduate students in his 47 years as an academic and was known for using his multilingual skills and photographic memory to make every class lecture come alive-at times accompanying them with his vivid newspaper clippings that he collected from his travels. In his classroom, the politics of the postcolonial world were peppered with vignettes of his experiences as a participant observer in the heyday of Africa's decolonization. He shared with his students the emergence of the political systems of diverse countries such as Benin, Cameroon, Cyprus, the Czech Republic, Eritrea, Ghana, France, Israel, the PRC, Rwanda, Saudi Arabia, Turkey, and Zaire (DRC).

A graduate of the University of California, Los Angeles (BA 1953; MA 1958; Ph.D. 1961), Victor Le Vine was one of the first cohort of Africanists trained by James S. Coleman. His seminal works on Cameroon and francophone Africa, The Cameroon from Mandate to Independence (1964), Political Corruption: The Ghana Case (1975), and Politics in Francophone Africa (2004) continue to be required readings for both graduate and undergraduate students specializing in francophone Africa. His interest in conflict resolution led him to specialize in comparative research in the politics of the Middle East and Afro-Arab countries, leading the publication of his book on Afro-Arab Connection: Political and Economic Realities (1979), which guided his later research on oil politics, corruption, and terrorism. A renaissance scholar, Le Vine was never limited by geographic boundaries and produced articles and chapters on informal politics and economics of disparate areas such as Somalia and Russia. He was also a consistent critique of ideological wars and actively sought to change the culture of conflict endemic in war-torn regions such as Israel/Palestine, Ireland, Cyprus, and Turkey. As a founding member of the Center for International Understanding (CIU), Le Vine strove tirelessly to include students, civil society organizations, diplomats, and policymakers in the use of dialogue as a means of fostering understanding.

Victor Le Vine is remembered for his insistence on empirical data and especially the importance he placed on research design and the formulation of the "question" or "puzzle" guiding his students' research. A repertoire heard by his hundreds of students was "What is the question?" often accompanied by his exhortation to keep "focused." Soft-spoken but firm, he mentored many students who would have been left on the margins of quantitative political science. His insistence on understanding history and factoring in the "human element" made him the teacher-of-choice for scholars who, like him, refused to be fenced in by academic boundaries. He welcomed not only students who specialized in comparative politics, but also those whose primary training was in African history, anthropology, sociology, and literature. Le Vine had a knack also for fostering the self-esteem of inquiring minds and guiding them through the maze of academic bureaucracy. His special courses dealing with "Law and International Politics" and "Guerrilla Wars and Terrorism" drew crowds, making him one of the most popular teachers in the department of political 